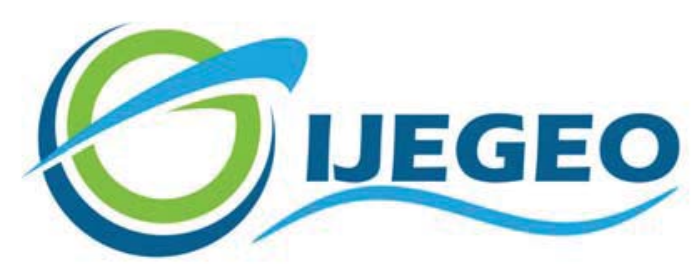

International Journal of Environment and Geoinformatics (IJEGEO) is an international, multidisciplinary, peer reviewed, open access journal.

\title{
A Cytogenetic and Morphological Study on Nannospalax ehrenbergi in Adana (Ceyhan) Province
}

\section{Tuncay TULUK, İIkay CIVELLEK, Cihan DÜŞGÜN, Teoman KANKILIÇ}

\author{
Chief in Editor \\ Prof. Dr. Cem Gazioğlu \\ Co-Editors \\ Prof. Dr. Dursun Zafer Şeker, Prof. Dr. Şinasi Kaya, \\ Prof. Dr. Ayșegül Tanık and Assist. Prof. Dr. Volkan Demir
}

Editorial Committee (December 2021)

\begin{abstract}
Assoc. Prof. Dr. Abdullah Aksu (TR), Assit. Prof. Dr. Uğur Algancı (TR), Prof. Dr. Bedri Alpar (TR), Assoc. Prof. Dr. Aslı Aslan (US), Prof. Dr. Levent Bat (TR), Prof. Dr. Paul Bates (UK), İrşad Bayırhan (TR), Prof. Dr. Bülent Bayram (TR), Prof. Dr. Luis M. Botana (ES), Prof. Dr. Nuray Çağlar (TR), Prof. Dr. Sukanta Dash (IN), Dr. Soofia T. Elias (UK), Prof. Dr. A. Evren Erginal (TR), Assoc. Prof. Dr. Cüneyt Erenoğlu (TR), Dr. Dieter Fritsch (DE), Prof. Dr. Çiğdem Göksel (TR), Prof.Dr. Lena Halounova (CZ), Prof. Dr. Manik Kalubarme (IN), Dr. Hakan Kaya (TR), Assist. Prof. Dr. Serkan Kükrer (TR), Assoc. Prof. Dr. Maged Marghany (MY), Prof. Dr. Michael Meadows (ZA), Prof. Dr. Nebiye Musaoğlu (TR), Prof. Dr. Masafumi Nakagawa (JP), Prof. Dr. Hasan Özdemir (TR), Prof. Dr. Chryssy Potsiou (GR), Prof. Dr. Erol Sarı (TR), Prof. Dr. Maria Paradiso (IT), Prof. Dr. Petros Patias (GR), Prof. Dr. Elif Sertel (TR), Prof. Dr. Nüket Sivri (TR), Prof. Dr. Füsun Balık Şanlı (TR), Prof. Dr. Uğur Şanlı (TR), Duygu Ülker (TR), Prof. Dr. Seyfettin Taş (TR), Assoc. Prof. Dr. Ömer Suat Taşkın (TR), Assist. Prof. Dr. Tuba Ünsal (TR), Dr. Manousos Valyrakis (UK), Dr. İnese Varna (LV), Dr. Petra Visser (NL), Prof. Dr. Selma Ünlü (TR), Assoc. Prof. Dr. Oral Yağcı (TR), Prof. Dr. Murat Yakar (TR), Assoc. Prof. Dr. İ. Noyan Yılmaz (AU); Assit. Prof. Dr. Sibel Zeki (TR)
\end{abstract}


Research Article

\title{
A Cytogenetic and Morphological Study on Nannospalax ehrenbergi in Adana (Ceyhan) Province
}

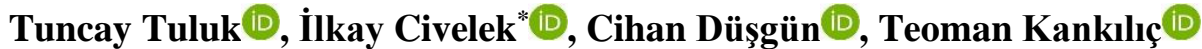

Department of Biotechnology, Faculty of Science and Letters, Niğde Ömer Halisdemir University, Niğde, Turkey

* Corresponding author: I. Civelek

Received 31.05.2021

E-mail: ilkaycivelek@ohu.edu.tr

Accepted 18.10.2021

How to cite: Tuluk et al., (2022). A Cytogenetic and Morphological Study on Nannospalax ehrenbergi in Adana (Ceyhan) Province,

International Journal of Environment and Geoinformatics (IJEGEO), 8(4):554-558, doi. 10.30897/ijegeo. 945101

\begin{abstract}
This study was conducted to explain the karyological analysis and morphological characteristics of blind mole rat samples collected from Ceyhan, Adana in Turkey. The chromosomes of the blind mole rat samples were stained and analysed using conventional methods. The chromosomes were defined according to centromere positions by processing photographs of metaphase cells. The karyotype of Nannospalax ehrenbergi showed 53 chromosomes $(2 \mathrm{n}=53)$ and fundamental number of chromosomal arms $\mathrm{NF}=66$ and the number of autosomal arms $\mathrm{NFa}=62$. The karyotype showed a hybrid individual. $\mathrm{X}$ and $\mathrm{Y}$ chromosomes were determined as metacentric and acrocentric, respectively. The autosomal set had 5 (+1 single homologous) pairs of metacentric/submetacentric and 20 pairs of acrocentric. Morphological studies were carried out on two male Nannospalax ehrenbergi skulls from Adana province. Lengths of three external (height, hindfoot length and weights (gr)) and 24 cranial morphological points on skulls were measured using an electronic caliper. This was the first study in which $2 \mathrm{n}=53 \mathrm{NF}=66$ population was determined from Ceyhan. This form was described as a hybrid form. The portion behind the palate (os palatinum) has no a sharply defined styloid process.
\end{abstract}

Keywords: Nannospalax ehrenbergi, Adana, Ceyhan, Karyotype, Morphology

\section{Introduction}

Blind mole rats are well-adapted to living underground. They spend their entire lives in the underground galleries they build, barely go above ground. They feed on plants such as roots, rhizomes, bulbs, and tubers that they find in the galleries. These species dig the soil by their incisors and at the same time throw excavated soil in the gallery using their flattened head like a bulldozer. As a result, the presence of soil mounds lined up at regular intervals along with the gallery created by the blind mole rats helps to identify the regions where these animals may be located (Figure 1). Therefore, behind the blind mole rat, a pile of soil forms, which are constructed at irregular intervals along with the gallery (Savic and Nevo, 1990; Sözen, 2005; Selvi et al., 2016; Guo et al., 2021).

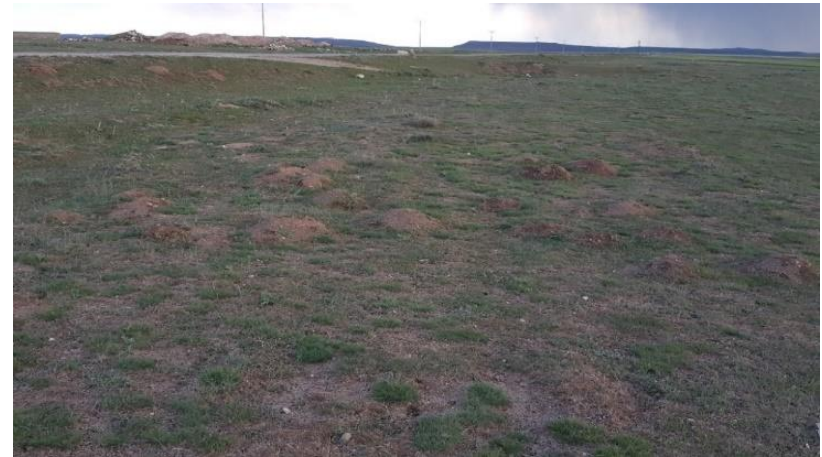

Fig. 1. Blind mole rat mounds.
The eyes of blind mole rats have evolved anatomical regression and are totally submerged under the skin, so they do not respond to light stimuli. Their head has approximately equal thickness with their body, and the shape of their body is cylindrical (Figure 2) (Harrison and Bates, 1991; Burda, 2006; Keleş et al., 2020).

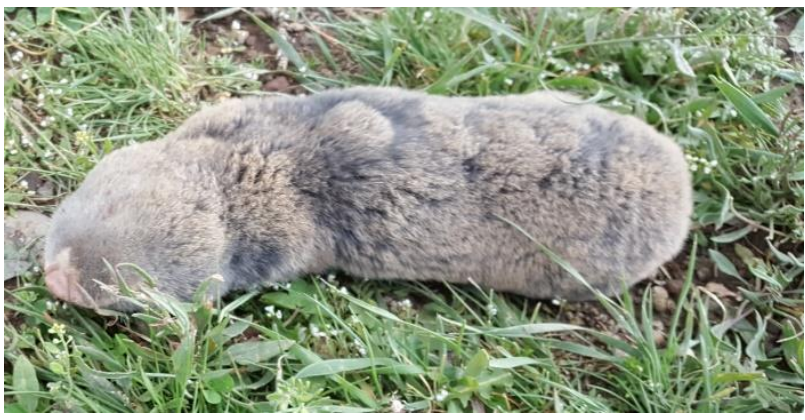

Fig. 2. A photograph of Nannospalax ehrenbergi.

The genus Nannospalax has extreme karyological variation, with more than 50 different cytotypes characterized by diploid chromosome number and other karyotypic characteristics compared to other rodents (Savic and Nevo, 1990, Topachevskii, 1969). Turkey blind mole rats have been represented by three species $(N$. xanthodon, $N$. ehrenbergi and $N$. leucodon). The differences in Anatolian blind mole rat karyotypes have been defined both between morphologically similar sibling species and distinct populations within each species (Arslan et al., 2011, Arslan et al., 2013, Kankılıç et 
al., 2017, Matur et al., 2013). In the Nannospalax ehrenbergi species, 12 different cytotypes were defined in terms of diploid chromosome numbers $(2 \mathrm{n}=48,52,54$, $56,58)$ and the number of autosomal arms $(\mathrm{NFa}=62,64$, 68, 70, 72) (Coşkun et al., 2006, Ivanitskaya et al., 1997, Nevo et al., 1995, Yüksel, 1984, Yüksel and Gülkaç, 1990). To date, some studies were conducted on Nannospalax ehrenbergi with $2 \mathrm{n}=52 \mathrm{NF}=74$ chromosome number in Osmaniye locality which was close to Ceyhan province (Coşkun, 2004, Coşkun et al., 2006). As a result, the number of defined cytotypes available in 3 species in Turkey has reached almost fifty. Since the cytotype abundance of listed blind mole rat species of Turkey and morphologically very close characteristics of cytotype within each species, it is significant to determine these cytotypes whether a separate taxon or not.

For this reason, this study is significant as it is the first research in which the $2 n=53 N F=66$ population from Ceyhan, Adana was determined and this form was designated as a hybrid form.

\section{Materials and Methods}

This research was conducted in two phases, in the field and in the laboratory. A total of three blind mole rat specimens were obtained from Ceyhan, Adana province in Turkey. The morphological characteristics of two blind mole rats were investigated, because one of them was juvenile.

\section{Cytogenetic Studies}

According to Ford and Hamerton, the "Colchicine Hypotonic Citrate" method was used to study the karyotypes of the animals captured in the field (Ford and Hamerton, 1956). In addition, blood and tissue samples were collected from the samples and stored in a $-80{ }^{\circ} \mathrm{C}$ deep freezer until DNA isolations. Karyotypes were prepared from bone marrow, approximately 25-30 metaphase cells were fully stained. Especially the cells were selected that were separate and distinct chromosomes to examine the animal. The diploid number of chromosomes (2n), fundamental number of autosomal arms of NFa, and the total number of chromosomal arms $(\mathrm{NF})$, metacentric (m), acrocentric (a), submetacentric (sm), and sex chromosomes were defined. Then, the karyotypes were prepared by matching the chromosomes using image processing software and arranged them in groups.

\section{Morphometric Studies}

The blind mole rat specimens collected from the field were transported alive to the lab in traps and placed in the animal care room for a while, external morphological measurements (body length, hindfoot length and weights (gr)) of the samples were recorded in accordance with the Animal Experiments Ethics Committee. Skulls of 2 adult male blind mole rats collected from Ceyhan, Adana province were used in the present study. This study was approved by the Animal Experiments Local Ethics
Committee of Niğde Ömer Halisdemir University with permission number $2016 / 23$.

Distances between 24 different points on skulls were measured with an electronic caliper and micrometer with $0.01 \mathrm{~mm}$ precision according to literature. The mean, standard deviation, and correlation values were calculated using SPSS 18.0 software for the collected measurements. Two-way Analysis of Variance (ANOVA) was used to estimate the variation between the averages of the measurements derived from the individuals of the populations analysed in the morphometric tests.

\section{Measurements of Cranial Characters}

The following characters were taken from each specimen (see also Figure 3 for skull variables):

1. Condylonasal Length, 2. Condylobasal Length, 3. Basal Length, 4. Occipitonasal Length, 5. Zygomatic Width, 6. Interorbital Constriction, 7. Nasal Length, 8. Skull Height, 9. Frontal-parietal Length, 10. Parietal Length, 11. Back Part Width of Parietalia, 12. Rostrum Width, 13. Righthand Foramen Infraorbital Length, 14. Upper Incisor Alveolar Width, 15. Anterior Palatal Length, 16. Hind Palatal Length, 17. Diastema Length, 18. Foramen Incisivum Length, 19. Median part width of upper incisor, 20. Upper Molar Alveolar Length, 21. Lower Molar Alveolar Length, 22. Articular Length of Lower Mandibule, 23. Mandible Height, 24. Auditory Meatus Diameter.

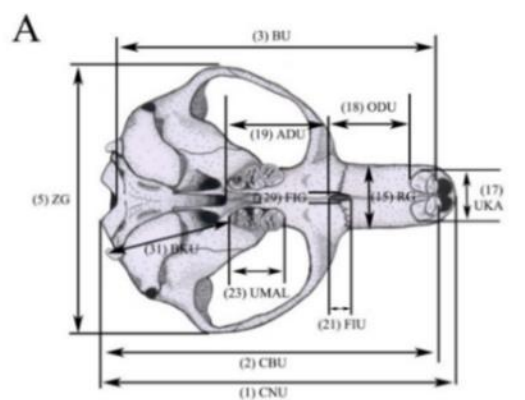

B

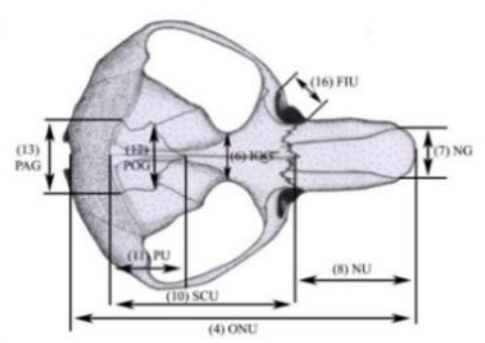

C

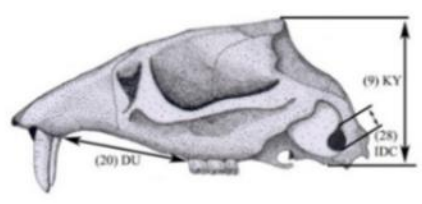

D

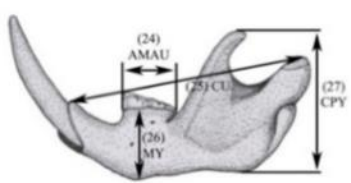

Fig. 3. Measuring Cranial Character Points on the Skull (Kankılıç et al., 2010). 


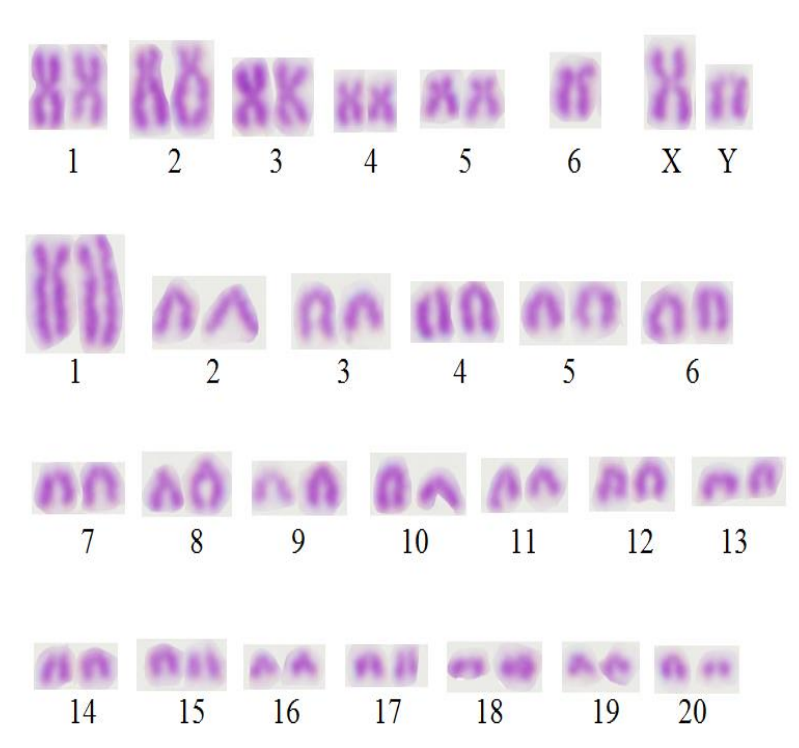

Fig. 4. The Karyotype of a Male from Adana (Ceyhan) Population.

\section{Results Karyology}

In this study, the karyotype analysis of specimens from various chromosomal forms of Nannospalax ehrenbergi species captured in field studies was done according to Ford and Hamerton's study (Ford and Hamerton, 1956). The study revealed that there is a population of the Nannospalax ehrenbergi in the Ceyhan district, Adana province. The karyotype analysis was performed in 3 male blind mole rats obtained from Adana (Ceyhan). The karyotype of a hybrid individual was $2 \mathrm{n}=53, \mathrm{NF}=66$ and $\mathrm{NFa}=62$. The $\mathrm{X}$ chromosome was metacentric, and $\mathrm{Y}$ chromosome was acrosentric.

The autosomal set contained 5 ( +1 single homologous) pairs of metacentric/submetacentric and 20 pairs of acrocentric (Figure 4).

\section{Morphology}

Three external (height, hind foot length and weights) and 24 cranial morphological characters were assessed in the specimens that we determined in Adana province as a part of the morphometry analysis. The means and standard deviations of the characters were determined for this cytotype. The average of the skull measurements of the individuals belonging to this cytotype and the standard deviation values are shown in Table 1.

\section{Discussion and Conclusion}

This research aimed to define the cytotype of blind mole rats captured from Adana (Ceyhan), using the karyological and morphological methods. The morphological and karyotypic characteristics of the blind mole rats were studied in detail in Ceyhan, Adana. Three blind mole rat samples taken from Ceyhan determined as a hybrid. This hybrid $(2 \mathrm{n}=53 \mathrm{NF}=66)$ was described for the first time for $N$. ehrenbergi. To date, 4 distinct cytotypes $(2 \mathrm{n}=48,52,56$, and 58$)$ have been described for $N$. ehrenbergi species based on the diploid chromosome number (Coşkun, 2004, Coşkun et al., 2006, Ivanitskaya et al., 1997, Sözen et al., 2006).

$2 n=48$ karyotype differs from the others because the number of metacentric autosomal chromosomes in this karyotype is higher than in the other $N$. ehrenbergi cytotypes. Szunyoghy identified a sample captured from 50 kilometers east of Adana as $N$. ehrenbergi var. ceyhanus (Szunyoghy, 1941). Coşkun and others examined the karyological and morphological characteristics of $N$. ceyhanus topotype samples and concluded that $N$. ceyhanus could be a valid taxon (Coşkun et al., 1999).

According to karyological analysis, this form had a value of $2 \mathrm{n}=56 \mathrm{NF}=72$, and morphologic studies revealed that this form had a spike on the back of the palate (palatal spike or styloid process) that was present in other $N$. ehrenbergi populations. It was concluded that the morphologic character was either very unclear or not present in individuals belonging to this form.

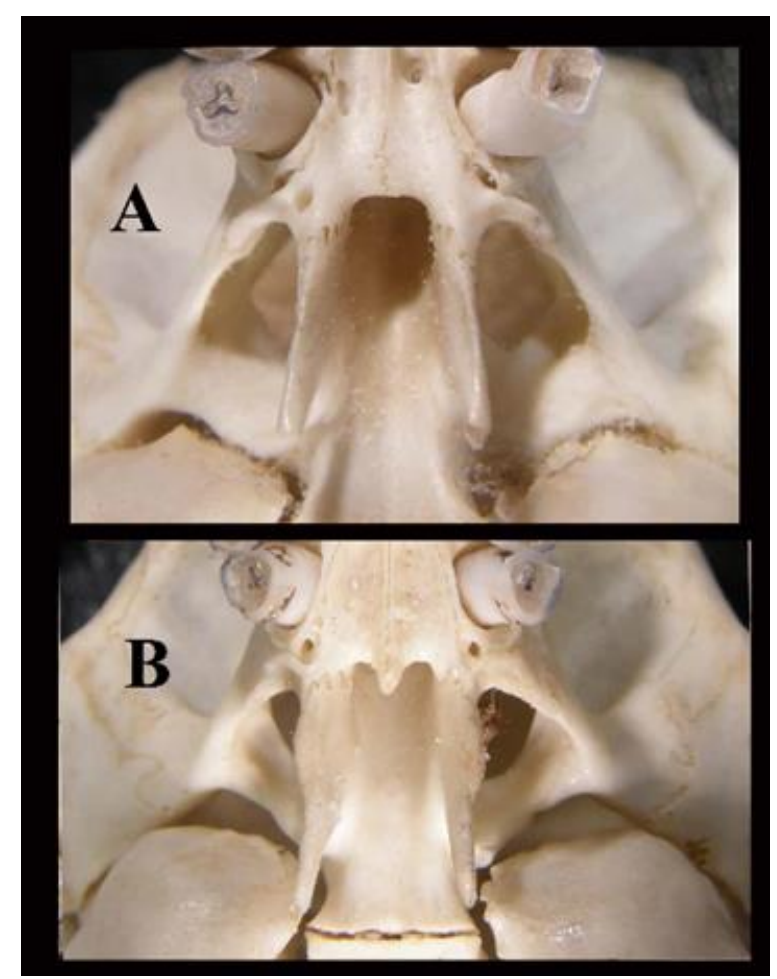

Fig. 5. The figure showing the situation absence (A) and presence (B) of a spike on the back of the palate (os palatinum)

The skull morphologies of samples from Adana populations were analyzed and it was determined that there was no or very little protrusion in the back of the palate, particularly in Adana samples (Figure 5). However, these differences in these populations may not be sufficient to evaluate populations with this karyotype as a separate taxon. The topotype of the sample captured by Szunyoghy from 50 kilometers east of Adana was uncertain. This situation removes some uncertainties as "Szunyoghy captured that sample from the hybrid localities of Ceyhan?" (Szunyoghy, 1941). 
Tuluk et al., / IJEGEO 8(4):554-558 (2021)

\begin{tabular}{|c|c|c|c|c|c|c|}
\hline Characters & $\mathrm{N}$ & Avg. & Std. dev. & Std. error & Min. & Max. \\
\hline Body Length & 2 & 195.5 & 3.5 & 2.5 & 193.0 & 198.0 \\
\hline Hindfoot Length & 2 & 25.5 & 0.7 & 0.5 & 25.0 & 26.0 \\
\hline Weight & 2 & 152.5 & 17.7 & 12.5 & 140.0 & 165.0 \\
\hline Conylonasal Length & 2 & 44.4 & 2.0 & 1.4 & 43.0 & 45.8 \\
\hline Conylobasal Length & 2 & 41.2 & 1.8 & 1.3 & 39.9 & 42.5 \\
\hline Basal Length & 2 & 39.2 & 1.7 & 1.2 & 38.0 & 40.4 \\
\hline Occipitonasal Length & 2 & 42.9 & 1.3 & 0.9 & 41.9 & 43.8 \\
\hline Zygomatic Width & 2 & 32.6 & 1.5 & 1.1 & 31.5 & 33.6 \\
\hline Interorbital Constriction & 2 & 6.4 & 0.4 & 0.3 & 6.1 & 6.6 \\
\hline Nasal Length & 2 & 16.9 & 0.2 & 0.2 & 16.7 & 17.0 \\
\hline Skull Height & 2 & 19.2 & 1.3 & 1.0 & 18.2 & 20.1 \\
\hline Frontal+Parietal Length & 2 & 16.7 & 3.0 & 2.2 & 14.5 & 18.8 \\
\hline Parietal Length & 2 & 8.0 & 0.6 & 0,4 & 7.6 & 8.4 \\
\hline Back Part Width of Parietalia & 2 & 11.6 & 0.4 & 0.3 & 11.3 & 11.8 \\
\hline Rostrum Width & 2 & 9.5 & 0.1 & 0.0 & 9.4 & 9.5 \\
\hline Right-hand Foramen Infraorbital Len. & 2 & 6.9 & 0.8 & 0.6 & 6.3 & 7.5 \\
\hline Upper Incisor Alveolar W. & 2 & 6.5 & 0.4 & 0.3 & 6.2 & 6.7 \\
\hline Anterior Palatal Length & 2 & 10.6 & 0.4 & 0.3 & 10.3 & 10.9 \\
\hline Hind Palatal Length & 2 & 12.8 & 0.4 & 0.3 & 12.5 & 13.0 \\
\hline Diastema Length & 2 & 15.5 & 1.0 & 0.7 & 14.8 & 16.2 \\
\hline Foramen Incisivum Len. & 2 & 3.2 & 0.1 & 0.1 & 3.1 & 3.3 \\
\hline Median part width of upper incisor & 2 & 2.1 & 0.1 & 0.1 & 2.0 & 2.2 \\
\hline Upper Molar Alveolar Len. & 2 & 8.0 & 0.2 & 0.2 & 7.8 & 8.1 \\
\hline Lower Molar Alveolar Len. & 2 & 7.5 & 0.1 & 0.1 & 7.4 & 7.6 \\
\hline Articular L. of Lower Man. & 2 & 27.0 & 1.1 & 0.8 & 26.2 & 27.8 \\
\hline Mandible height & 2 & 15.4 & 0.8 & 0.6 & 14.8 & 16.0 \\
\hline Auditory Meatus Diameter & 2 & 3.4 & 0.4 & 0.3 & 3.1 & 3.6 \\
\hline
\end{tabular}

As a consequence, this case should be carefully investigated in order to determine the distribution field of the hybrid form. It was admitted that this hybrid formed between $2 n=52 N$. ehrenbergi cytotypes from the South East to Ceyhan borders and $2 \mathrm{n}=54$ cytotypes identified for $N$. ehrenbergi, according to morphological analysis and karyotype morphological structures (Nevo, 1969).

Nevo reported that rare natural hybrids among karyotypes occur along the contact zones. For example, in Israel, hybrid zones are available among the chromosomal forms, and these forms have been described as distinct species (Nevo, 1969). On the other hand, for this study, a hybrid population is most likely to occur with a population belonging to the $2 \mathrm{n}=52$ form found in Osmaniye and Hatay and the $2 \mathrm{n}=54$ form found in
Tufanbeyli (Adana), the closest region to Ceyhan (Adana). Consequently, the hybrid zone where the $2 \mathrm{n}=$ 54 and $2 n=52$ forms intersect is described as Ceyhan.

Accurate evaluation of species distribution and their taxonomic status is a fundamental need to address biological diversity in any geographical region. This is the most essential prerequisite to begin biodiversity management and conservation planning studies. Therefore, the determination of the geographical distribution of the diploid chromosome forms and available cytotypes of the populations that have never been studied before karyological blind mole rats will provide a correct estimation for the taxonomic classification of these species in future studies. 


\section{References}

Arslan, A., Akan, Ş., Zima, J. (2011). Variation in Cheterochromatin and NOR distribution among chromosomal races of mole rats (Spalacidae) from Central Anatolia, Turkey. Mammalian Biology, 76(1), 28-35.

Arslan, A., Arısoy, A., Zima, J. (2013). The chromosome banding pattern in two cytotypes $(2 \mathrm{n}=36$ and 38$)$ of blind mole rats from Turkey (Mammalia: Spalaxidae). Zoology in the Middle East, 59(2), 95-100.

Burda, H. (2006). Ear and eye in subterranean mole-rats, Fukomys anselli (Bathyergidae) and Spalax ehrenbergi (Spalacidae): progressive specialisation or regressive degeneration?. Animal Biology, 56(4), 475486.

Coşkun, Y. (2004). A new species of mole rat, Nannospalax munzuri sp. n., and the karyotype of Nannospalax tuncelicus (Coşkun, 1996) (Rodentia: Spalacidae) in eastern Anatolia. Zoology in the Middle East, 33(1), 153-162.

Coşkun, Y., Ulutürk, S., Yürümez, G. (2006). Chromosomal diversity in mole-rats of the species Nannospalax ehrenbergi (Rodentia: Spalacidae) from South Anatolia, Turkey. Mammalian Biology, 71(4), 244-250.

Ford, C. E., Hamerton, J. L. (1956). A colchicine, hypotonic citrate, squash sequence for mammalian chromosomes. Stain Technology, 31(6),247-251.

Guo, Y. T., Zhang, J., Xu, D. M., Tang, L. Z., \& Liu, Z. (2021). Phylogenomic relationships and molecular convergences to subterranean life in rodent family Spalacidae. Zoological Research, 42(5), 671.

Harrison, D. L., Bates, P. J. J. (1991). The Mammals of Arabia. Harrison Zoological Museum.

Ivanitskaya, E., Coskun, Y., Nevo, E. (1997). Banded karyotypes of mole rats (Spalax, Spalacidae, Rodentia) from Turkey: a comparative analysis. Journal of Zoological Systematics and Evolutionary Research, 35(4), 171-177.

Kankılıç, T., Arslan, A., Şeker, P. S., Kankılıç, T., Toyran, K., Zima, J. (2017). A new chromosomal race $(2 n=44)$ of Nannospalax xanthodon from Turkey (Mammalia: Rodentia). Zoology in the Middle East, 63(3), 181-188.

Kankılıç, T., Kankılıç, T., Seker, P., Çolak, R., Selvi, E., Çolak, E. (2010). Contributions to the karyology and distribution areas of cytotypes of Nannospalax leucodon (Rodentia: Spalacidae) in Western Anatolia. Acta Zoologica Bulgarica, 62(2), 161-167.

Keleş, A. İ., Süt, B. B., Kankılıç, T. (2020). Histopathological Analysis of The Eye And Optic Nerve Structure In The Blind Mole Rat. Dicle Tip Dergisi, 47(3), 638-644.

Matur, F., Çolak, F., Ceylan, T., Sevindik, M., Sözen, M. (2013). Chromosomal evolution of the genus Nannospalax (Palmer 1903) (Rodentia, Muridae) from Western Turkey. Turkish Journal of Zoology, 37, 470-487.

Nevo, E., Filippucci, M. G., Redi, C., Simson, S., Heth, G., Beiles, A. (1995). Karyotype and genetic evolution in speciation of subterranean mole rats of the genus
Spalax in Turkey. Biological Journal of the Linnean Society, 54(3), 203-229.

Savic, I. R., Nevo, E. (1990). The Spalacidae: evolutionary history, speciation and population biology. Progress in Clinical and Biological Research, 335, 129-153.

Selvi, E., Kankılıç, T., Şeker, P. S., Çolak, E. (2016). Morphometric analysis of Nannospalax leucodon (Nordmann, 1840) with 2n=60 distributed in Central Anatolia. Communications Faculty of Sciences University of Ankara Series C Biology, 25(1), 33-55.

Sözen, M. (2005). A biological investigation on Turkish Spalax Guldenstaedt, 1770 (Mammalia: Rodentia). Gazi University Journal of Science, 18(2), 167-181.

Sözen, M., Matur, F., Çolak, E., Ozkurt, Ş., Karataş, A. (2006). Some karyological records and a new chromosomal form for Spalax (Mammalia: Rodentia) in Turkey (Vol. 55): Institute of Vertibrate Biology.

Szunyoghy, J., (1941). Two new species of mole rats from Asia Minor, Allattani Kozlemenyek (in Hungarian with German summary) 38, 78-86.

Topachevskii, W. A. (1969). Fauna of the USSR: mammals: mole rats, spalacidae. New Delhi, India: American Publication Company.

Yüksel, E. (1984). Cytogenetic study in Spalax (Rodentia: Spalacidae) from Turkey: Communications, Serie C.

Yüksel, E., Gülkaç, M. D. (1990). The evolution and phylogenetic relationships in some subspecies and chromosomal forms of Spalax leucodon. Turkish Journal of Biology, 14, 59-68. 